UNITED STATES DEPARTMENT OF THE INTERIOR

Harold L. Ickes, Secretary

GEOLOGICAL SURVEY

W. C. Mendenhall, Director

\title{
Bulletin 936-P
}

\section{VANADIUM DEPOSITS OF COLORADO AND UTAH}

\section{A PRELIMINARY REPORT}

\author{
BY \\ RICHARD P. FISCHER \\ Prepared in cooperation with the \\ STATE OF COLORADO and the \\ COLORADO METAL MINING FUND
}

Strategic Minerals Investigations, 1942

(Pages 363-394)

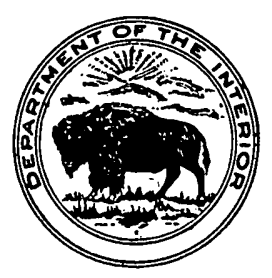

UNITED STATES

GOVERNMEN'T PRINTING OFFICE

WASHINGTON : 1942

For sale by the Superintendent of Documents, Washington, D. C. - . - - . - Price 30 cents 



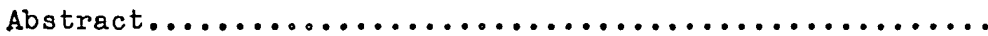

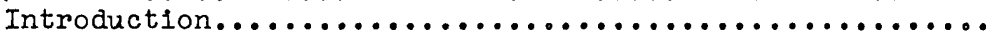

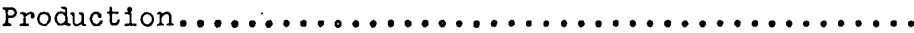

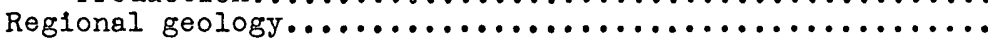

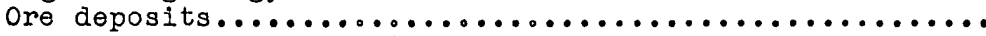

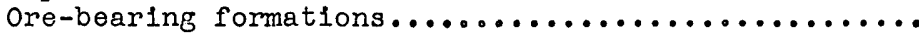

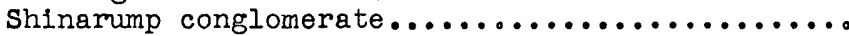

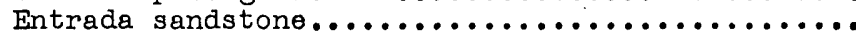

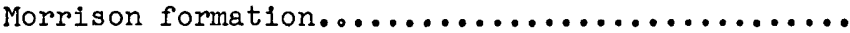

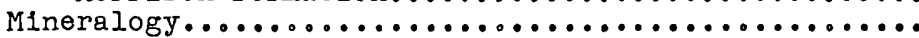

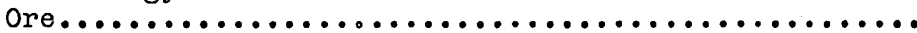

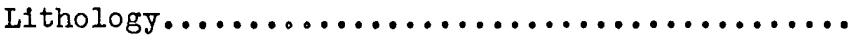

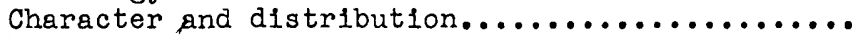

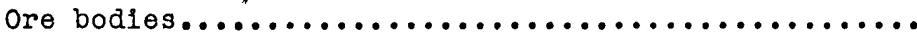

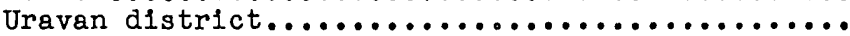

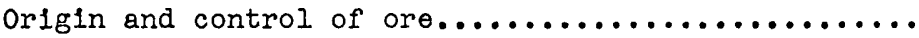

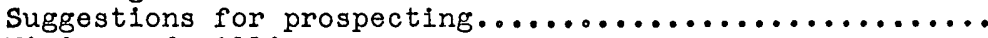

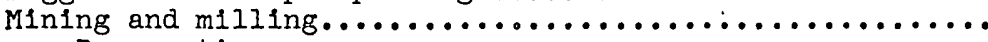

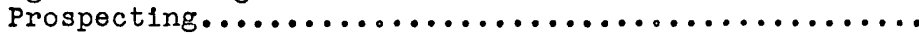

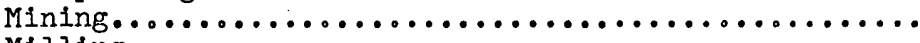

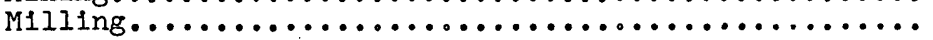

364

365

366

367

367

367

371

376

379

379

379

382

385

387

389

393

393

394

394

\section{ILLUSTRATIONS}

Page

Plate 53. Index map of part of Colorado, Utah, and Arizona, showing the location of the sig-

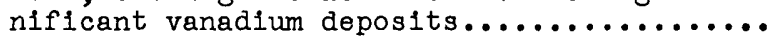

54. A, Photomicrograph of sandstone impregnated with vanadium-bearing hydrous mica; $\underline{B}$, Typical face of vanadium ore..............

55. A, Zone of vanadium ore cutting across bedding; $B$, Thin zone of rich vanadium ore along contact of ore body and barren sand-

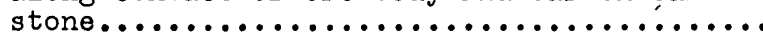

56. A, Paraliel zones, resembling diffusion bands, of rich vanadium ore along the edge of an ore body; $\underline{B}$, Lens of shale-pebble conglomerate, in part mineralized and in part barren.

57. Geologic map and section of the club group of mines, Montrose County, Colorado............ 
Page

Figure 43. East-west cross section through the Rifle mine (after Bla1r Burwell)

Figure 44. Measured stratigraphic sections of the Entrada sandstone in the Placerville district, showing the position of the vanadium- and chromium-bearing layers.......... 373

Figure 45. Map of the Placerville district, showing the outcrops of the vanadium- and chromium-

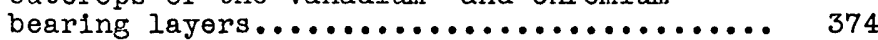

Figure 46. Cross-section of an ideal ore body.......... 384

Figure 47. Geologic map of the Uravan area, Montrose County, Colorado. 


\title{
VANADIUM DEPOSITS OF COLORADO AND UTAH
}

\author{
A PRELIMINARY REPORT
}

\author{
By Richard P. Fischer
}

\section{ABSTRACT}

Deposits of vanadium-bearing sandstone are widely distributed in western Colorado and eastern Utah and have been the principal domestic source of vanadium, uranium, and radium. Except during a few years when operations were relatively small, deposits at one or more places in this region have been intensively mined since 1909. Production has increased considerably each year since 1937.

Most of the deposits are in the Morrison formation, but there are two important deposits in the Entrada sandstone and several small deposits in the Shinarump conglomerate. Recent $\mathrm{X}$-ray studies indicate that the principal vanadium mineral, heretofore considered to be roscoelite, belongs to the hydrous mica group of clay minerals. This mineral, along with other vanadium minerals of minor importance, impregnates sandstone. Shale pebbles and clay films on bedding planes in ore-bearing sandstone are rich in absorbed vanadium, and fossil plants in and adjacent to ore bodies are richly mineralized with vanadium and uranium in places. Vanadium ore of milling grade contains from about 1 to 5 percent $\mathrm{V}_{2} \mathrm{O}_{5}$, and most of it contains less than 1 percent $\mathrm{U}_{3} \mathrm{O}_{8}$. Ore contalining as much as $1 \frac{1}{2}$ percent $\mathrm{U}_{3} \mathrm{O}_{8}$ is usually sold as uranium ore. The vanadium-bearing hydrous mica is in part uniformly disseminated through the sandstone and in part concentrated along bedding planes and in thin zones that cut across bedding. As the zones that cut across bedding are curved or wavy, they are called rolls by the miners.

The ore bodies are spotty and form irregularly tabular masses that lie essentlally parallel to the sandstone beds, but they do not follow the beds in detail. They range in content from a few tons of ore to many thousand tons. The trend of many elongate bodies is indicated by the orientation of the rolls within the ore, and this trend also suggests the probable alinement of any adjacent ore bodies; mapping of ore bodies and rolls is - therefore an aid to prospecting and development.

No satisfactory explanation can yet be offered for the origin of these deposits. The ore bodies do not appear to have been localized by such geologic structures as fractures or folds, but within Ifmited areas they are restricted to certain stratigraphic zones. 


\section{INTRODUCTION}

Deposits of vanadium-bearing sandstone, containing some uranium and radium, are widely distributed in western Colorado and eastern Utah, and some occur in northern Arizona (pl. 53). These deposits have been the principal domestic source of vanadium, uranium, and radium. In 1939 the Geological Survey, United States Department of the Interior, in cooperation with the State of Colorado and the Colorado Metal Mining Fund, began a geologic study of these ores in the western part of Montrose County, Colo., where many of the largest known deposits of this type have been found. The present report, which describes the significant geologic features of these deposits, is based on this study and on brief visits to many of the other vanadiumproducing areas in the region.

The work was begun under the guidance of Mr. B. S. Butler of the Geological Survey. S. P. St. John, Charles Meyer, 0. J. Myers, and A. P. Butler, Jr., have assisted in the field work. The producing companies and many individuals in the vanadium region gave generous aid and cooperation. H. G. Ferguson and F. C. Calkins contributed many helpful suggestions during the preparation of the report.

\section{Production}

In 1899 a yellow mineral from the sandstones of the western part of Montrose County was found to contain uranium, vanadium, and radium; and this mineral was named carnotite. From 1911 to 1923 ores containing carnotite were intensively mined in Montrose County and adjacent areas; radium and uranium were the constituents desired, but from 1915 to 1923 some vanadium was produced as a byproduct. Mining of these ores practically ceased in 1923, when the Belgian Congo pitchblende began to supply radium. Since 1937 these ores again have been intensively mined, but 
this time primarliy for vanadium. Vanadium was produced from vanadium-bearing sandstone at Placerville, Colo., from 1909 to 1923, and at Rifle, Colo., from 1925 to 1932. Vanadium ore was being mined at both localities in 1941.

Vanadium production from the Colorado-Utah region, as expressed in pounds of metallic vanadium contained in the mill product obtained, is summarized in the following table:

Vanadium production from Colorado and Utah (in pounds of metallic vanadium)

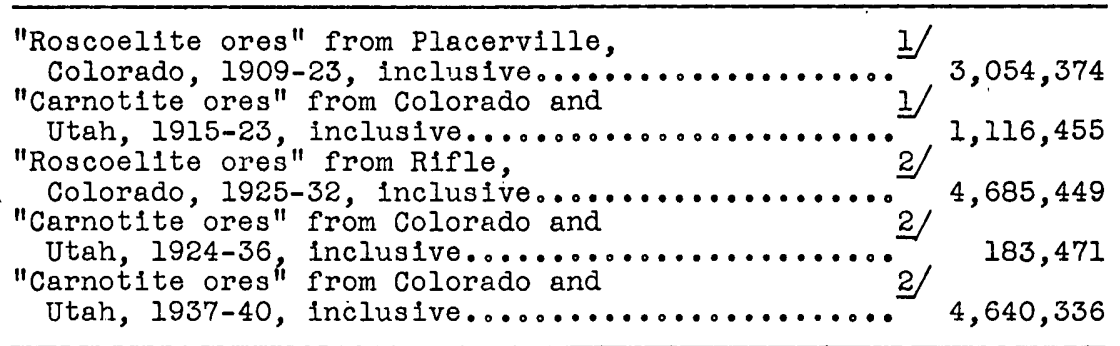

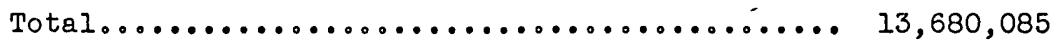

1/ Mineral Resources U. S., 1924, pt. 1, p. 473, 1927.

2/ Compiled with the aid of Frederick Brtz, Jr., from the files of the U. S. Sureau of Mines.

\section{REGIONAL GEOLOGY}

The regicn containing most of the vanadium deposits constitutes approximately the northeastern third of the Colorado Plateau physiographic province. Much of this region, being dissected by many rugged canyons, is commonly known as the Canyon Lands. Except for some of the canyon bottoms and high mountain masses, most of the region ranges in altitude from about 5,000 to 7,500 feet above sea level. The climate is semiarid except in the high mountain areas.

The formations exposed consist mostly of nearly horizontal sedimentary beds, disturbed in places by moderately strong monoclinal and anticlinal folds and high-angle faults. The Comb Ridge and Water Pocket monoclines and the San Rafael Swell and Uncompahgre Plateau uplifts are the largest folds in the region, 
but strong anticlines underlie Paradox Valley, Spanish Valley, and other similar topographic features in the vicinity of the La Sal Mountains. Steeply dipping faults displace the beds along the flanks of these folds in many places, and competent sandstone beds in the vicinity of these folds are much jointed.

The sedimentary beds in western Colorado and eastern Utah range in age from late Paleozolc to Tertiary. All known vanadium deposits of economic importance are found in the shinarump conglomerate, of Triassic age, and the Entrada sandstone and Morrison formation, of Jurassic age. The lithologic features, topographic expression, distribution, and variations in thickness of the Triassic and Jurassic formations in this region are summarized in the table on pages 368-371.

Moderate-sized igneous bodies of Tertiary age have intruded these sediments and are exposed in the La Sal, Abajo, El Late (Ute), Carrizo, and Henry Mountains.

\section{ORE DEPOSITS}

The vanadium deposits of western Colorado, eastern Utah, and northern Arizona, although of wide areal distribution, have a narrow stratigraphic range. All known deposits of economic importance in the region are restricted to the Shinarump, Entrada, and Morrison formations, and at many places the deposits are largely or wholly confined to a single stratigraphic zone in one of these formations. The ore, however, is not confined to a single sandstone bed or lens. The ore is mostly sandstone impregnated with vanadium minerals, but shale pebbles and clay flims along bedding planes in the ore-bearing sandstone are rich in absorbed vanadium, and fossil plants in and adjacent to ore bodies are in places richly mineralized. As the vanadium content of the ore is not uniform, highly selective mining is required to obtain ore of the desired grade. Vanadium ore of milling grade contains from about $I$ to 5 percent $\mathrm{V}_{2} \mathrm{O}_{5}$, and most 


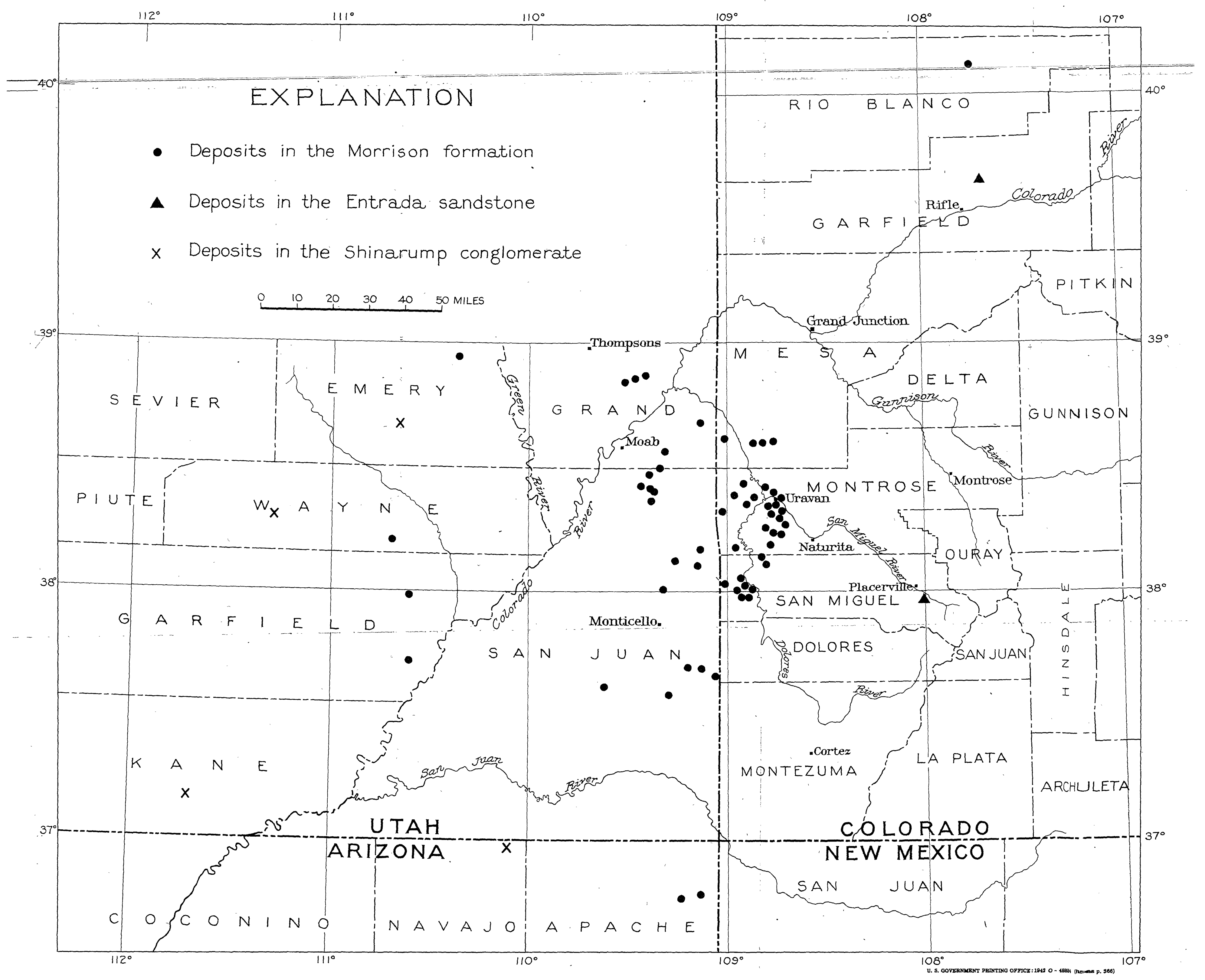


of It contains less than 1 percent $\mathrm{U}_{3} \mathrm{O}_{8}$. Ore contalning as much as $1 \frac{1}{2}$ percent $\mathrm{U}_{3} \mathrm{O}_{8}$ is commonly sacked and sold separately as uranium ore.

The ore bodies are extremely spotty and form irregularly tabular masses that lie essentially parallel to the sandstone beds, but do not follow the beds in detail. In places, curved or wavy structures in the ore, called rolls by the miners, are oriented in a common direction, and this orientation may indicate the trend or elongation of the ore body. Adjacent bodies are also likely to be alined along this trend. The ore bodies do not appear to have been localized by fractures or folds.

\section{Ore-bearing formations}

Shinarump conglomerate.--The only known important deposit of vanadium and uranium in the Shinarump conglomerate is at Temple Mountain, in Emery County, Utah. This deposit has not been visited by the writer but has been described by Hess. I/ Small deposits in the Shinarump conglomerate occur in southern Utah and northern Arizona (pl. 53). These have some features in common with the deposits in the Morrison formation.

Entrada sandstone.--At the U. S. Vanadium Corporation's mine, about 12 miles northeast of Rifle, Colo., most of the ore is in the lower part of a 20- or 30-foot bed of cross-bedded, gray sandstone, included in the Entrada sandstone in this report. This bed lies on the Dolores formation, and it is overlain by about 100 feet of characteristic Entrada sandstone. A cross section through the mine, drawn by Burwell, shows a close relationship between the distribution of the ore and the crossbodding ( $f 1 g .43$ ); however, the mineralized sandstone that extends laterally from the ore body forms a single slightly

I/ Hess, F. L., Uranium-bearing asphaltite sediments of Utah: Fing. and Min. Jour.-Press, vol. 114, pp. 272-276, 1922.

2/ Burwell, Blair, Mining methods and costs at the vanadium mine of the U. S. Vanadium Corooration, Rifle, Colo.: U. S. Bur. Mines Inf. Circ. 6662, f1g. 2, 1932. 


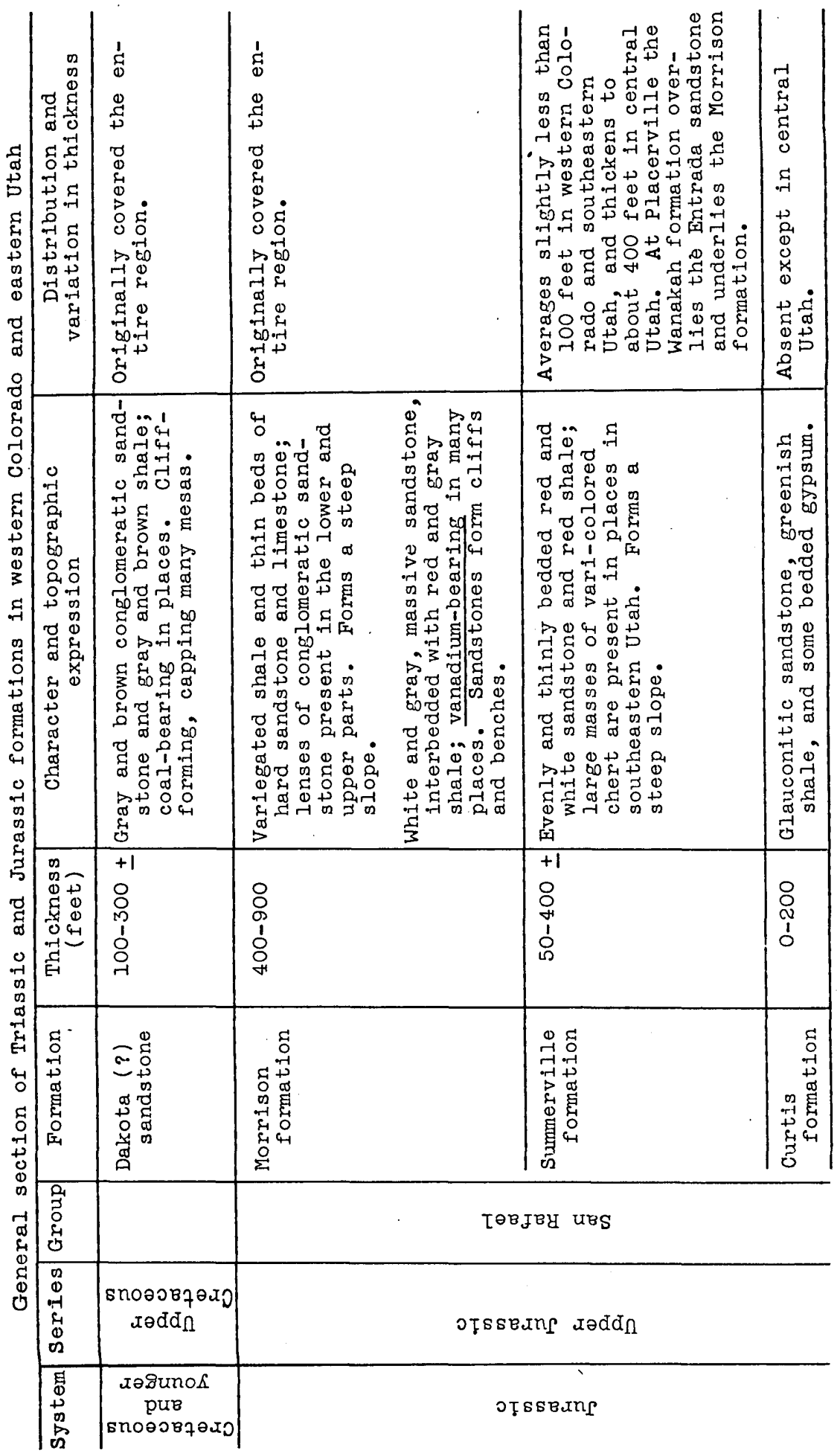


1.

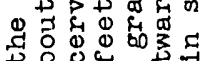

क वै त्व के

$+10$

วิ 0 क ल

की

ว

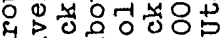

दृ 401000

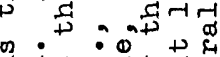

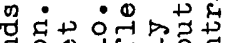
दि

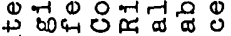

$\times$

离

$j_{2}$

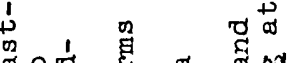

๘엻

ॠ

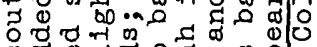

क ठृ

ర

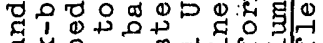

क ते

0 .

ब

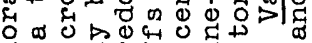

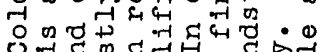

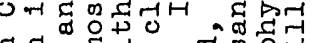

स त 0 ब

4 $\begin{aligned} & 0 \\ & 0\end{aligned}$

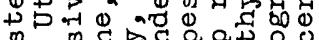

क द व क्ष

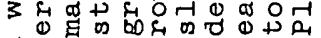

品

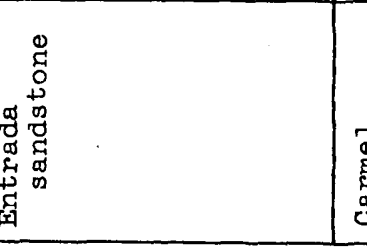

โөBJBY UBS

ofsรBung Jөddก

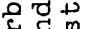

द

ì

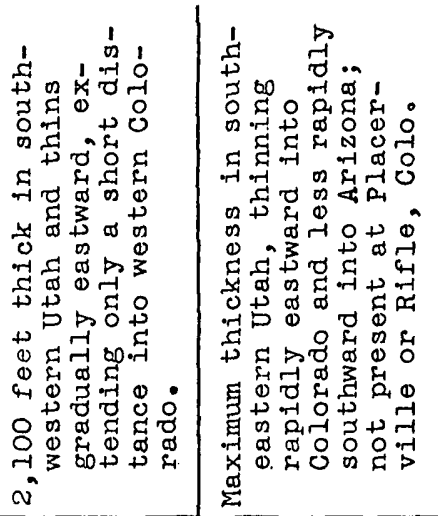

+2,

$\sin 0$.

$\rightarrow$ क ष

o 3

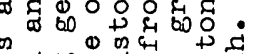

क स 0 के क्ष

नक्ष

娄者

द ब क क्ष

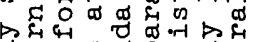

ठ 0 \%

द्य

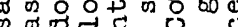

ठ

क्ष

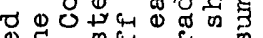

व

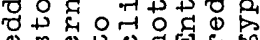

o on $\begin{aligned} & 0 \\ & 0\end{aligned}$

络 द⿱

क्षेत्ट

Э댕

वृ

T) 0 क

गु मे

वृ क्षन

Dने

ซ

o :

कूत

\&्व

(

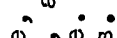

$\rightarrow \infty$

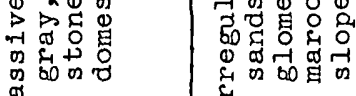

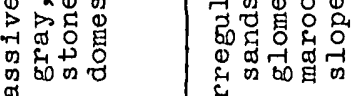

¿ 8 b०

0,54

वृ मू०

वृ हैन

कृष

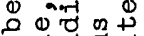

$\rightarrow$ व

$\rightarrow \infty 0$.

दू कि

가난 3

品中田。

व

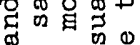

a

$\rightarrow 00$

7 दि

舟

$\rightarrow$ o 0 잉

क्ष

出

\begin{tabular}{l|l}
\hline 8 & \\
\hline 8 & \\
\hline
\end{tabular}

\begin{tabular}{|l|l}
0 & 8 \\
0 & 0 \\
0 & 0 \\
1 & 1
\end{tabular}

옴

1

\begin{tabular}{|c|c|c|c|}
\hline & '́ & ó & ' \\
\hline 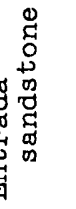 & 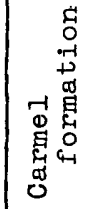 & 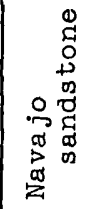 & 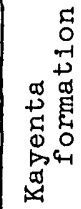 \\
\hline
\end{tabular}

\begin{tabular}{|c|c|}
\hline TӨBJBY UBS & UOLUBD UəTD \\
\hline ofssBung Iөddn & \\
\hline
\end{tabular}

(d) ofsseinf 


\begin{tabular}{|c|c|c|c|c|}
\hline 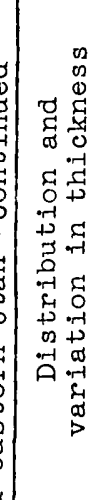 & 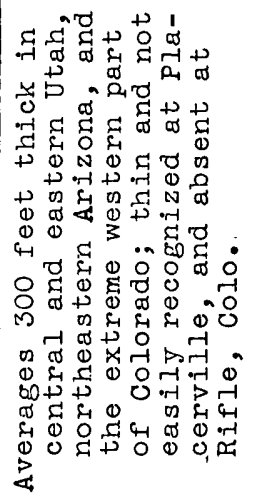 & 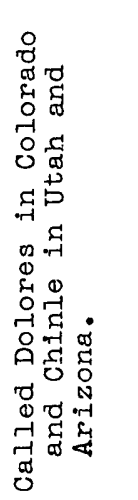 & 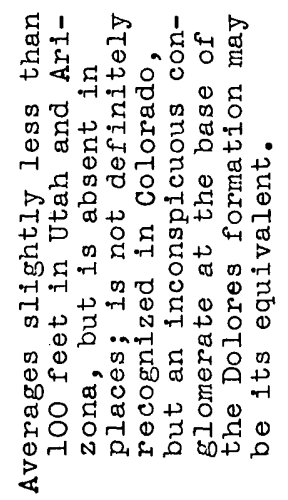 & 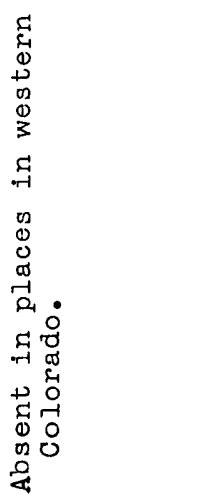 \\
\hline 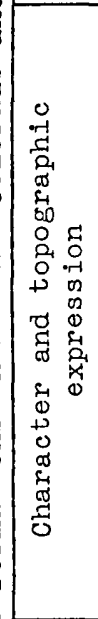 & 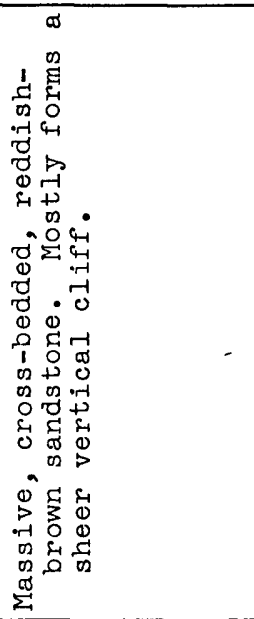 & 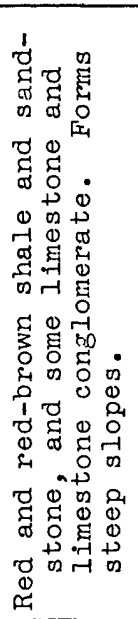 & 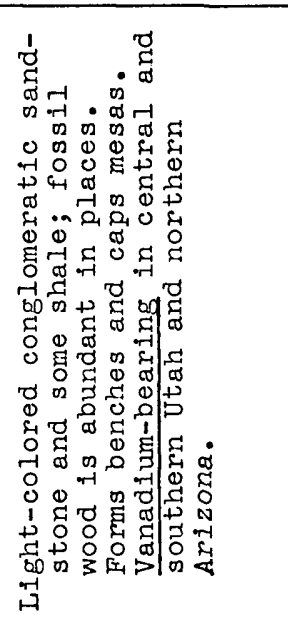 & 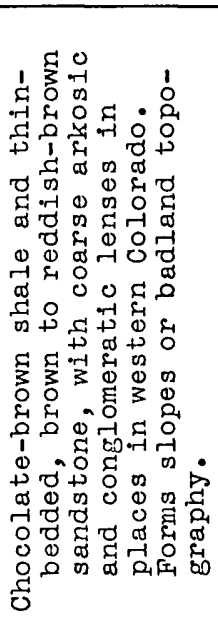 \\
\hline 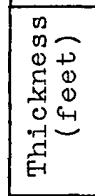 & $\begin{array}{l}0 \\
\text { t } \\
1 \\
0\end{array}$ & $\begin{array}{l}8 \\
8 \\
0 \\
1 \\
0 \\
0 \\
-1\end{array}$ & $\begin{array}{l}+1 \\
+1 \\
8 \\
0 \\
1 \\
1 \\
0\end{array}$ & $\begin{array}{l}8 \\
\varnothing \\
\infty \\
1 \\
0\end{array}$ \\
\hline 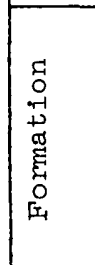 & 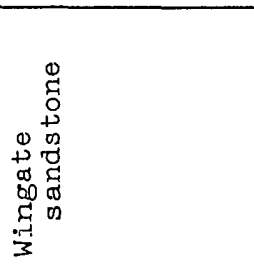 & 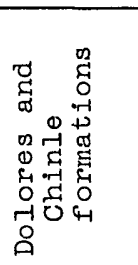 & 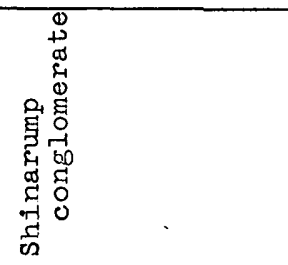 & 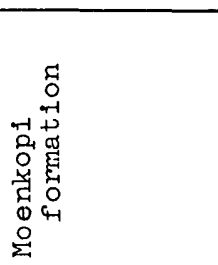 \\
\hline $\begin{array}{l}0 \\
0 \\
0 \\
0 \\
\dot{8}\end{array}$ & น०КUвอ นәTD & & & \\
\hline $\begin{array}{l}0 \\
0 \\
0-1 \\
\vdots \\
0 \\
0\end{array}$ & & & & \\
\hline $\begin{array}{l}E \\
5 \\
+ \\
0 \\
0 \\
0\end{array}$ & (d) ofssiunf & & Of SธBF & \\
\hline
\end{tabular}




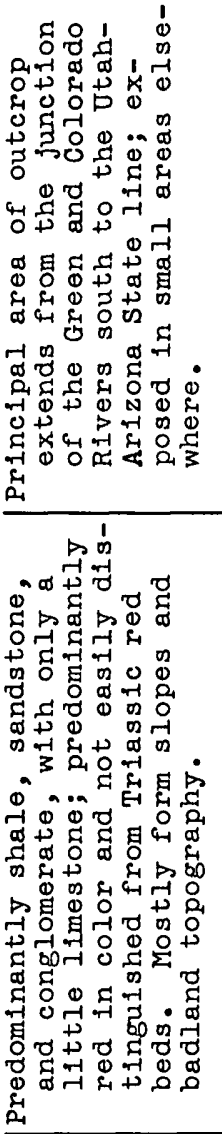

a.

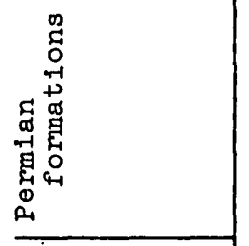

speq xөрто pus uв futred undulant layer, too thin or too lean to be of commercial value. This layer lies in the basal few feet of the formation and extends through the cross-bedding with only a minor concentration of minerals along cross-bedding planes. It is continuous for at least a mile along the outcrop.

In the Placervilie district, vanadium ore is restricted to the upper 10 or 15 feet of the Entrada sandstone ${ }^{3}$ (f1g。 44). Before the erosion of the present stream valleys a single, slightly undulant layer of vanadium-bearing sandstone covered an elongate area of trend at least 3 by 9 miles in extent (f1g. 45). The parts of this layer that are about 2 feet or more thick and contain about $1 \frac{1}{2}$ percent or more of $\mathrm{V}_{2} \mathrm{O}_{5}$ constitute ore bodies. A few feet below most of the vanadium-bearing layer is a layer of light-green sandstone colored by a finely disseminated chromium mineral (figs. 44 and 45 ).

Morrison formation.--In western Colorado and eastern Utah the Morrison formation can conveniently be divided into two lithologic units of about equal thickness. The lower unit consists of massive lenses of medium- to coarsegrained, rather porous sandstone, partly conglomeratic at some places in Utah, interbedded with red and gray shale. These sandstones form a series of cliffs, and in many places a sandstone at the top of the lower unit makes a rather consplcuous bench. The upper unit forms a steep

3/ The Intrada sandstone at Placerville was formerly called "lower La Plata" by the Geological survey, a tern that is still used by many people in that area. 
slope below the cliff of Dakota (?) sandstone and is composed of gray, red, green, purple, and brown shale and of thin beds of hard sandstone and limestone. Thick lenses of sandstone, in part conglomeratic, occur locally in both the lower and upper parts of this unit." The two units are not sharply separated, particularly where sandstone lenses are present in the lower part of the upper unit. The measured section of the Morrison formation, given on page 375 , is typical.

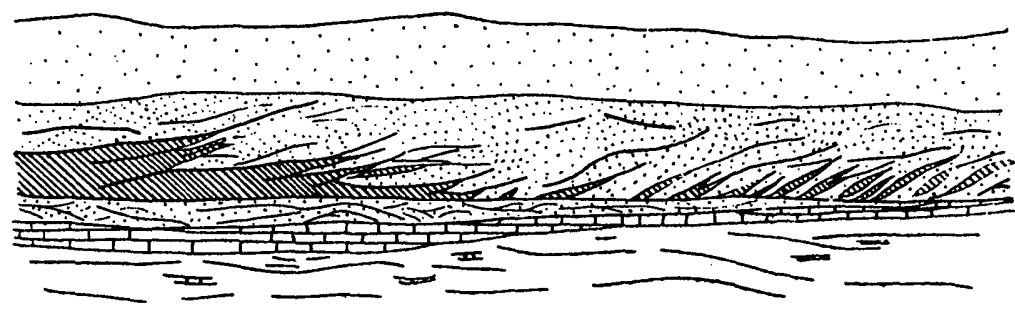

McElmo sandstone (cross-bedded)

LEGEND Vanadium-bearing sandstone

La Plata limestone

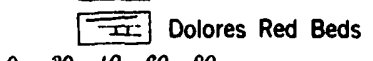

$0.40 \quad 60 \quad 80$
Scalb, feet

Figure 43.-- Bast-west crose section through the Rifle mine of the U. S. Vanadiun Corporation, Rifle, Colo. (After Blalr Burwell, Mining methods and costs at the vanadium mine of the U. S. Vanadium Corporation, Rifle, Colo.: U. S. Bur, Mines Inf. C1rc. 6662, fig. 2, 1932.) The beds labelled MCElmo sandstone in the figure are classified as Entrada sandstone in the present report, and the beds below the vanadium-bearing sandstone as Dolores formation.

In the carnotite region of Mesa, Montrose, and San Miguel Counties, Colo., and the adjacent part of Utah, most of the ore occurs in the sandstone lenses that occupy the stratigraphic zone at the top of the lower unit. Many of these lenses are more extensive than other sandstone lenses in the formation; a single lens may be as much as 60 feet thick and several miles long. It is the opinion of many observers that the more favorable places for ore are those where the sandstone is relatively thick, but some ore has been found where the sandstone is thin. Most of the ore is found in the lower parts of sandstone lenses, but ore bodies may occur anywhere from the bottom to the top of 


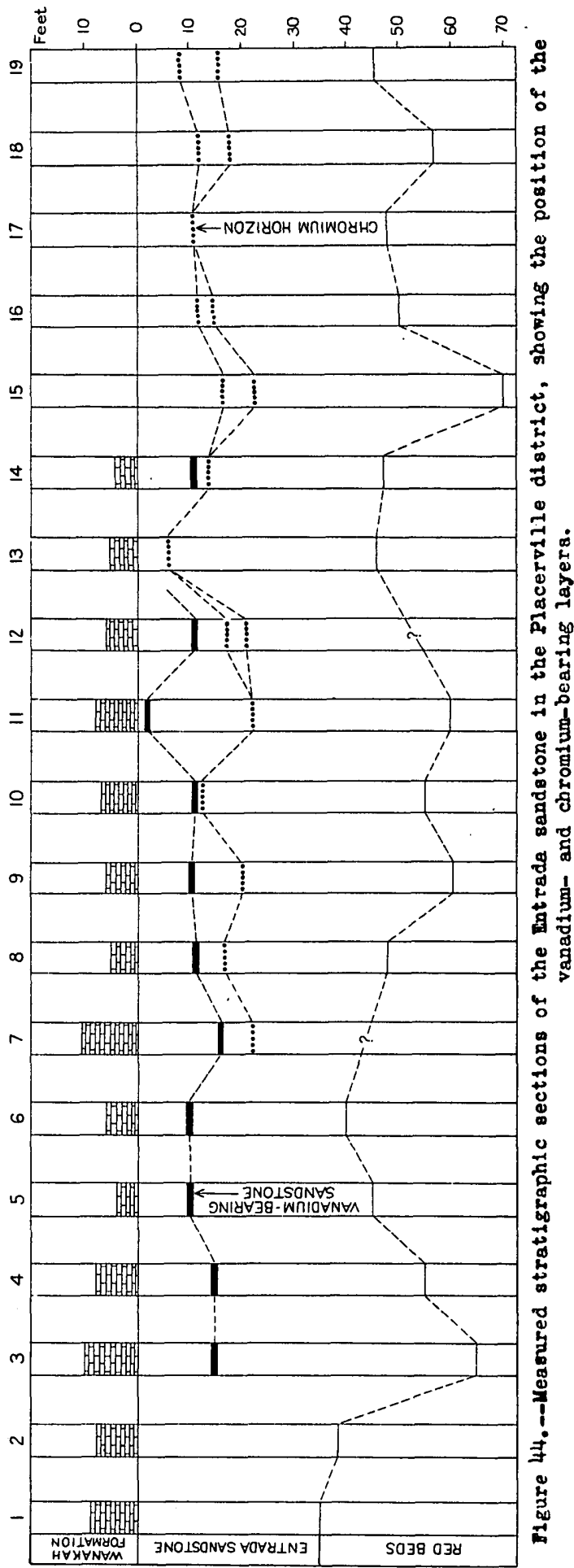


a lens. The lower part is apparently more favorable for bodies of milling-grade vanadium ore, whereas the upper part is more favorable for small bodies of high-grade uranium ore ("tree formations"). In some mines, however, there are two or more rather distinct levels of milling-grade vanadium ore, separated by as much as 20 or 30 feet of barren sandstone. In places a thick shale lens lies within, or tongues into, an ore-bearing sandstone lens.

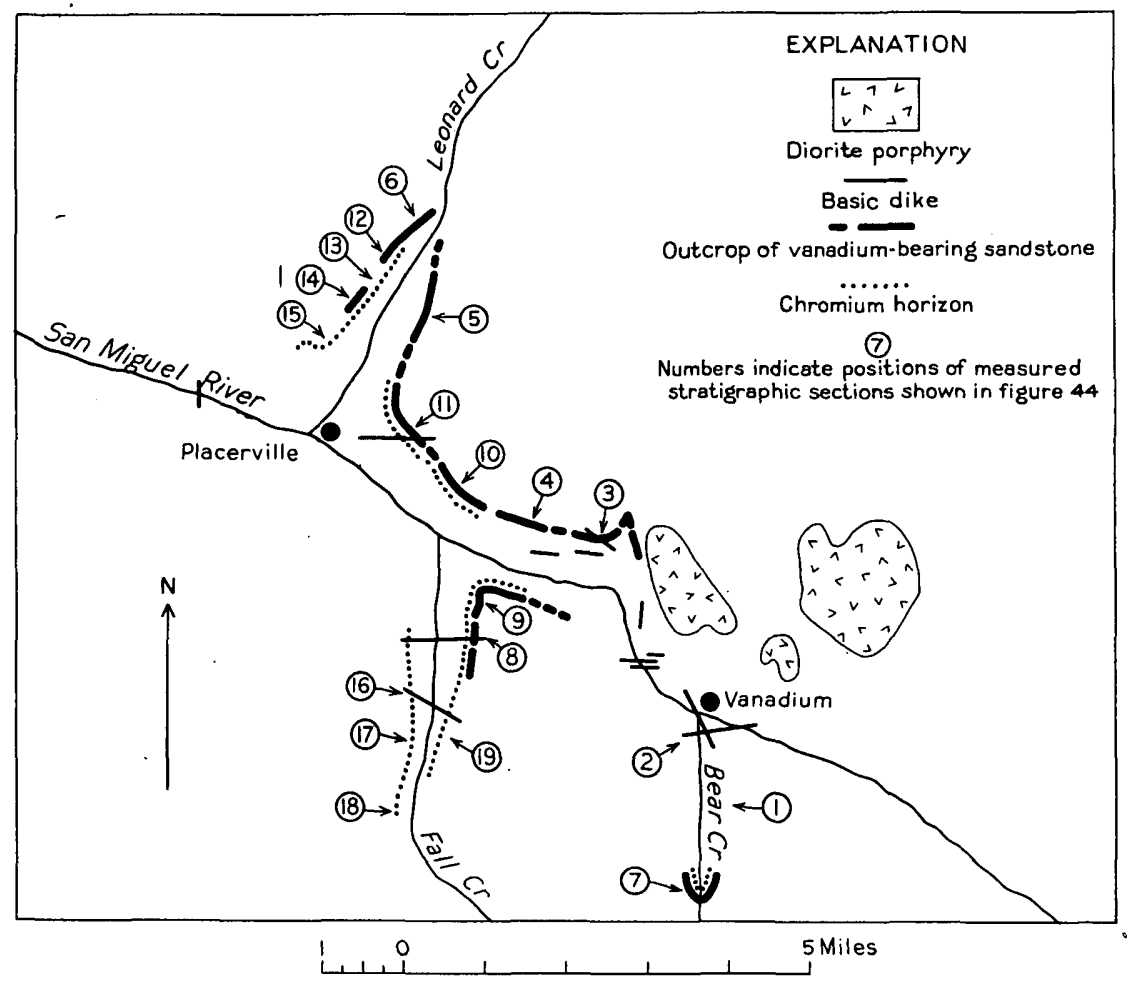

Figure 45.--Map of the Placervilie district, showing the outcrops of the vanadium- and chromium-bearling layers.

As the sandstones that are most favorable for ore occupy the upper part of the lower unit and are bench-forming, it is possible in many places to prospect for and outline ore bodies, at small expense, by drilling from the surface of the bench. Ore has been found in sandstones lower in the formation, but all of 1t, so far as known, in bodies too small to be of much economic interest. 
Section of Morrison formation at the Dolores group of mines, near the junction of Dolores and San Miguel Rivers, Montrose County, Colorado

Dakota (?) sandstone:

Feet

Sandstone, white, weathering brown; medium- to coarsegrained, with lenses of conglomerate; resistant and cliff-forming.

Morrison formation:

Upper unit:

1. Shale, varlegated, with thin and discontinuous beds of hard sandstone and limestone; poorly exposed; forms slope.....................

2. Sandstone, light gray, coarse-grained and conglomeratic, massive, friable............ 40

3. Shale and thin sandstone; forms covered slope..

Lower unit:

4. Sandstone, light brown and light gray, mediumto coarse-grained, massive to lenticularly and Irregularly bedded, cross-bedded; forms vertical cliff and bench; ore-bearing........

5. Shale, red except upper few feet, which are gray, with thin sandstone lenses; forms

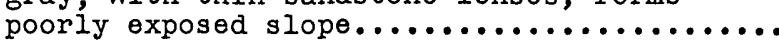

6. Sandstone, light brown and light gray, mediumto coarse-grained, massive to lenticularly and irregularly bedded, cross-bedded; forms vertical cliff........................

7. Sandstone, shaly, with shale lenses; sandstone is light gray, coarse-grained, massive, soft and friable; shale is reddish and sandy......

8. Sandstone, like No. $6 \ldots \ldots \ldots \ldots \ldots \ldots \ldots \ldots \ldots . \ldots$

9. Shale, like No. $5 \ldots \ldots \ldots \ldots \ldots \ldots \ldots \ldots \ldots \ldots \ldots . \ldots \ldots$

10. Sandstone, light gray to buff, medium- to coarse-gralned, thick-bedded, cross-bedded;

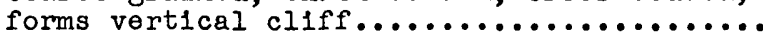

Sunmerville formation:

Sandstone, argillaceous sandstone, and shale, red, gray, and light-colored, in thin even beds or massive; forms a slope and is poorly exposed...........

Entrada sandstone.

4/ The Geological Survey has recently extended the formation name "Summerville" to include about 80 feet of beda heretofore included in the lower part of the Morrison formation in the mestern parts of Mega, Montrose, San ylguel, Dolores, and Montezuma Counties, Colorado. 
The two-fold division of the Morrison formation is also recognized south of Monticello, Utah, but ore bodies are scattered throughout the sandstones in the upper half of the lower unit instead of being restricted to a zone at the top of this unit.

The shales interbedded with the sandstones in the lower unit of the Morrison formation are red except immediately below sandstone, where, for a thickness of from 1 to 5 feet, they have been altered to gray or greenish gray by solutions circulating through the sandstone and penetrating the upper part of the shale. This altered shale is the so-called blue clay of the miners and drillers.

\section{Mineralogy}

Vanadium and uranium, plus the radioactive products of uranium, are the only economically important constituents of the ore, which, however, contains traces of copper and silver in places. The deposits in the Entrada sandstone are commonly referred to as the "vanadiferous sandstone deposits," or "roscoelite deposits," as. they contain only a trace of uranium. The deposits in the Morrison formation, on the other hand, are generally referred to as the "carnotite deposits," a term that has been carried over from the time of the earlier operations, when carnotite was the desired mineral because of the uranium and radium it contained. These deposits, however, contain several times as much vanadium as uranium, and the bulk of the vanadium is apparently in the same mineral form as in the deposits in the Entrada sandstone. As most of the ore minerals are exceedingly fine grained and many of them are intimately mixed or intergrown, mineralogic studies of the ore are difficult.

The principal vanadium mineral is micaceous, and it has heretofore been thought to be roscoelite, the vanadium mica; but, as a result of recent X-ray studies by Sterling Hendricks 
of the Department of Agriculture, it is now thought to belong to the imperfectly understo,od hydrous-mica group of clay minerals. The general formula for this group is probably $2 \mathrm{~K}_{2}$ 0.3RO.$8 \mathrm{R}_{2} \mathrm{O}_{3} \cdot 24 \mathrm{~S}_{2} \mathrm{O}_{2} \cdot 12 \mathrm{H}_{2} \mathrm{O} \cdot \mathrm{RO}$ includes magnesia (MgO) and ferrous Iron ( $\mathrm{F} \theta \mathrm{O})$, and $\mathrm{R}_{2} \mathrm{O}_{3}$ includes alumina $\left(\mathrm{Al}_{2} \mathrm{O}_{3}\right)$ and ferric iron $\left(\mathrm{Fe}_{2} \mathrm{O}_{3}\right)$. Presumably vanadium oxide $\left(\mathrm{V}_{2} \mathrm{O}_{3}\right)$ replaces $\mathrm{Al}_{2} \mathrm{O}_{3}$ and $\mathrm{Fe}_{2} \mathrm{O}_{3}$ to form the vanadium-bearing member of this group. The vanadium-bearing hydrous mica forms an aggregate of minute flakes, coating the sand grains (see pl. 54, A), and it appears to be the earliest ore mineral. Where mineralization was weak to moderate, a single layer of this mineral was deposited on the sand grains, and the central parts of the pore spaces of the sandstone remained empty, or in places were fllled by a later, nonvanadiferous clay mineral (dickite?). Where the sandstone was more strongly mineralized, the pore spaces are completely filled with the vanadium mineral. This mineral imparts to the sandstone a gray or greenish-gray color, which darkens as the vanadium content increases.

At several places in Montrose County; especially in the mines in the Long Park area (see fig. 47), some of the ore, when dry and viewed by daylight, has the yellowish-brown color of Ilmonite; but underground, while it is still molst and when viewed by the light of a carbide lamp, the same material appears distinctly reddish, and the miners call it "red oxide ore." The color is due to a finely disseminated brown mineral, not jet identified, which has replaced, or possibly been formed along with, the vanadium-bearing hydrous mica. This type of ore is mostly of good grade, containing about 2 percent $\mathrm{V}_{2} \mathrm{O}_{5}$, but it is rarely rich. It forms masses of various sizes and irregular shapes within the ore bodies.

Vanoxite $\left(2 \mathrm{~V}_{2} \mathrm{O}_{4} \cdot \mathrm{V}_{2} \mathrm{O}_{5} \cdot 8 \mathrm{H}_{2} \mathrm{O}\right)$ is an important ore mineral in the Jo Dandy mine of Montrose County, and in the nearby

5/ Orim, R. R., Brag, R. H., and Bradley, F. I. The mica in argillaceous sediments: Am. Mineralogist, vol. 22, pp. 813-829, 1937. 
prospects; and there is some vanoxite in the ore at many local1ties in Colorado and Utah. It forms black, prismatic crystals partly or completely filling the interstitial spaces of the sandstone; it replaces the vanadium-bearing hydrous mica and partiy replaces the sand grains. Corvusite $\left(\mathrm{V}_{2} \mathrm{O}_{4} \cdot 6 \mathrm{~V}_{2} \mathrm{O}_{5} \cdot \mathrm{nH}_{2} \mathrm{O}\right)$, a massive, purplish blue-black mineral, is intimately mixed with vanoxite where gypsum is present in the ore-bearing sandstone. This mixture replaces carbonized fossil plants and Impregnates the adjacent sandstone, and it is commonly called kentsmithite by the miners.

Fervanite $\left(2 \mathrm{Fe}_{2} \mathrm{O}_{3} \cdot 2 \mathrm{~V}_{2} \mathrm{O}_{5} \cdot 5 \mathrm{H}_{2} \mathrm{O}\right)$, hewettite $\left(\mathrm{CaO} \cdot 3 \mathrm{~V}_{2} \mathrm{O}_{5} \cdot 9 \mathrm{H}_{2} \mathrm{O}\right)$, and metahewettite (same composition as hewettite) are secondary minerals of similar habit. They may be disseminated in the sandstone, but for the most part they form velnlets along fractures that cut the ore. These minerals are closely associated with gypsum, which they may replace. Fervanite is brown, hewettite and metahewettite are red; all are fibrous with a silky luster.

Pascolte $\left(2 \mathrm{CaO} .3 \mathrm{~V}_{2} \mathrm{O}_{5} \cdot 11 \mathrm{H}_{2} \mathrm{O}\right)$, rossite $\left(\mathrm{CaO} \cdot \mathrm{V}_{2} \mathrm{O}_{5} \cdot 4 \mathrm{H}_{2} \mathrm{O}\right)$, and metarossite $\left(\mathrm{CaO} \cdot \mathrm{V}_{2} \mathrm{O}_{5} \cdot 2 \mathrm{H}_{2} \mathrm{O}\right)$ form efflorescent coatings on protected surfaces where vanadium-bearing ground vater evaporates. They form most abundantly on surfaces of vanoxite and corvusite ore. Pascoite is bright orange, rossite and metarosite are light yellow.

The principal uranium-bearing minerals are carnotite (approximately $\mathrm{K}_{2} \mathrm{O} \cdot 2 \mathrm{UO}_{3} \cdot \mathrm{V}_{2} \mathrm{O}_{5} \cdot 3 \mathrm{H}_{2} \mathrm{O}$ ) and tyuyamunite (approximately CaO.2UO $3 \cdot \mathrm{V}_{2} \mathrm{O}_{5} \cdot 4 \mathrm{H}_{2} \mathrm{O}$--sometimes called calclum carnotite), but the two are not easily distinguished. Both minerals are yellow. Carnotite is apparently the powdery or earthy material that is irregularly disseminated through the ore and incompletely replaces fossil plants. Its age relations are not clear, but it

6/ H1llebrand, 7. F. Carnotite and tyuyamunt te and their ores in Colorado and Utah: Am. Jour. Sc1., 5th ser., vol. 8, pp. 201-216, 1924. 
probably formed relatively early. Tyuyamunite is apparently the finely crystalline material that occupies open spaces, such as the pores of the sandstone and open fractures; it may form in ore-bearing sandstone or in otherwise barren sandstone even at a distance of several feet from ore. It is obviously secondary and formed relatively late.

Ore

Lithology:--The lithologic character of the sandstone in the ore-bearing beds is variable. The sandstone is massive in places, but for the most part it consists of a complex assemblage of lenses and channel f1lls; Irregular bedding and crossbedding are common. In the Morrison formation and the Shinarump conglomerate, lenses of shale are irregularly interbedded with the sandstone, and shale pebbles, resulting from partial erosion and redeposition of the mud layers that now form the shale lenses, are scattered through the sandstone or are concentrated as irregular lenses of shale pebble conglomerates. In these two formations fossil plants, consisting of logs, leaves, and reeds, are scattered through the sandstone or are irregularly concentrated as if they were buried as tangled bunches at the time the sands were being deposited. No fossil plant material has been recognized in the ore-bearing parts of the Entrada sandstone. The sandstone of the Entrada is mostly fine-grained; that of the Morrison and Shinarump is mostly medium- to coarsegrained.

Character and distribution.--The ore was formed by selective 'Impregnation of sandstone, absorption by shaly material, and mineralization of fossil plants. The vanadium-bearing hydrous mica is in part disseminated rather uniformly through the sandstone and in part concentrated in sheets along bedding planes (pl. 54, B) or in zones, up to several inches thick, that cut across the bedding ( $p l .55)$. The zones may lie in barren or 
weakly mineralized sandstone (pl. 55, A) or along the contact of ore and barren sandstone, forming a sort of shell around the ore body (pls. 55, B and 56, A). Because these zones are curved or wavy they are called rolls by the miners.

Where mineralization was strong, especially along the favorable bedding planes or along the rolls, there has been solution of the quartz grains in the sandstone. This process first formed microscopic styolitic seams between adjacent sand grains and then continued unt1l the grains were completely removed. As the quartz grains have not been replaced by the vanadium mineral, there has been an appreciable decrease in the volume of the mineralized rock. Where considerable quartz was removed, the residual concentration of the vanadium mineral formed a soft, vanadium-rich, shalelike seam along bedding planes and a "veinlet" along the rolls that cut across the bedding. The volume change is most evident where the rolls cut across bedding planes at a moderate angle, causing a minor slumping of the bedding planes (see pl. 55). Ransome, and later Fischer, incorrectly Interpreted these seams as shale seams of sedimentary origin, whereas Hess 9 more correctly considered them to be veinlets. In places there is a fracture along a veinlet (see pl. 55, A).

Vanadium is richly concentrated in the shale pebbles in the ore-bearing sandstone of the Morrison formation; one selected sample, consisting of several pebbles, contalned $12 \frac{1}{2}$ percent $\mathrm{V}_{2} \mathrm{O}_{5}$. The mineralized pebbles are black and brittle. Pebbles half an inch or less across are mineralized throughout, but the larger pebbles are mineralized only in the outer part, the central part consisting of barren gray or red shale. The vanadium

I/ Hillebrand, N. Ec, and Ransorne, F. I., On carnotite and assoclated vanadiferous minerals in western Colorado: U. s. Geol. Survey Bull. 262, p. $14,2905$.

$8 /$ Fischer, B. P., Sedimentary deposits of copper, vanadium-uranium, and silver in southrestern Ontted States: Bcon. Geol., vol. 32, pp. 906-951, 1937.

2/ Hess, I. I., In Ore deposits of the Mestern States (IIndgren rolume), p. 459, Am. Inst. Min. Met. Ing., 1933. 
was able to penetrate only about a quarter of an inch into the shale pebbles, and it likewise penetrated about a quarter of an Inch into bedded shale in contact with ore-bearing sandstone. Vanadium was also concentrated in small grains of clay scattered through the sandstone, and in clay films on bedding and crossbedding planes (see pl. 54, B).

In places the ore tends to follow the lenses of shale-pebble conglomerate, and there are two reasons why it might be expected to do so everywhere: These lenses should offer permeable channels for mineralizing solutions, and the shale pebbles are able to absorb and concentrate the vanadium. But in many places the boundary of the ore cuts sharply across these lenses (pl. 56, B) for no apparent reason. Where the boundary of the ore is especially sharp, pebbles as small as an inch across are richly mineralized on the side lying within the ore and barren on the other side.

The fosil plants in the Morrison formation consist of tree trunks and branches, reeds, and leaves. Most trunks were drifted into place--the ends appear rounded and the branches are broken or worn off. Several trunks found in the Club group of mines (pl. 57), however, evidently had merely fallen over from the place of growth, for attached to the root system is a disk of clay that is several feet in diameter and a couple of feet thick. These trunks are enclosed in massive sandstone and lie about 6 or 8 feet above a shale bed that appears to have been the soil in which the trees grew.

The logs are in various states of preservation: many are partly replaced with dolomite, calcite, or silica, which may or may not enclose some residual carbonaceous matter; some are partly hollow or filled with sand; some are changed to coal; and some are partly replaced with ore minerals. Most logs are somewhat flattened; the ore-bearing logs have been more flattened, in general, than those that were replaced with carbonate or 
silica. The reeds and leaves are altered to carbonaceous films; in places they occur singly, but in many places they were buried in the sands as tangled bunches.

In general, the plant material is mineralized only where it is enclosed in ore-bearing sandstone. Some logs that project from an ore body into the surrounding barren sandstone are mineralized within the ore body and barren outside it; other logs projecting into barren sandstone are mineralized from end to end as if the mineralizing solutions followed the logs. Not all of the plant material in ore-bearing sandstone is richly mineralized, however, and the coaly material especially is essentially barren. In places small pockets of high-grade ore are associated with plant material in otherwise barren sandstone and at some distance from known ore bodies; these are comonly called tree formations by the miners. The ore minerals partly fill cavities resulting from disintegration of the fossil plants or incompletely replace the woody structure; it is rare to find the woody stmucture well-preserved in ore-bearing material. The ore mineral most commonly associated with the mineralized fossil plants is carnotite, but in places a dark gray, claylike, vanadium-rich material is also present.

\section{Ore bodies}

The ore bodies range from small masses only a few feet across, containing only a few tons of ore, to large tabular bodies of irregular outline several hundred feet across, containing as much as a hundred thousand tons of ore; most bodies contain from a few hundred to a few thousand tons of ore. The tabular ore bodies tend to lie essentially parallel to the sandstone beds, but they do not follow the beds in detail. The limit of the vanadium-bearing sandstone in many bodies is sharpIy defined and in places is actually the limit of commercial ore. Elsewhere the limit of commercial ore is less clearly 


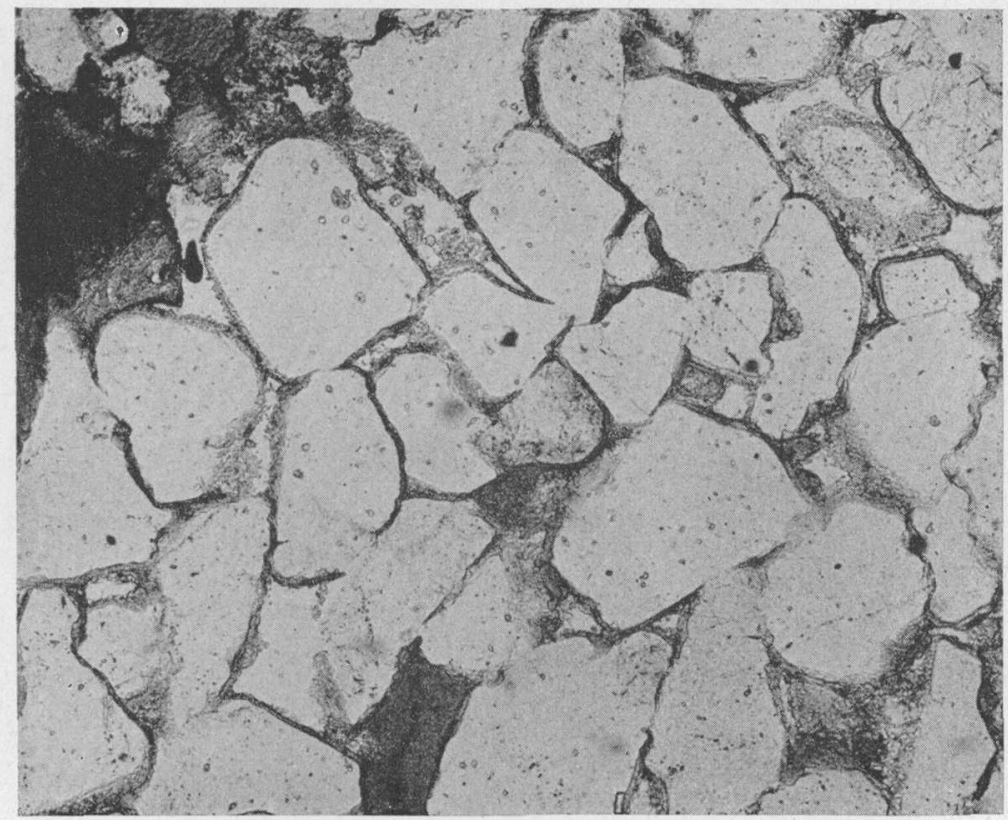

A. PHOTOMICROGRAPH OF SANDSTONE IMPREGNATED WITH VANADIUM. BEARING HYDROUS MICA (DARK). $\times 95$.

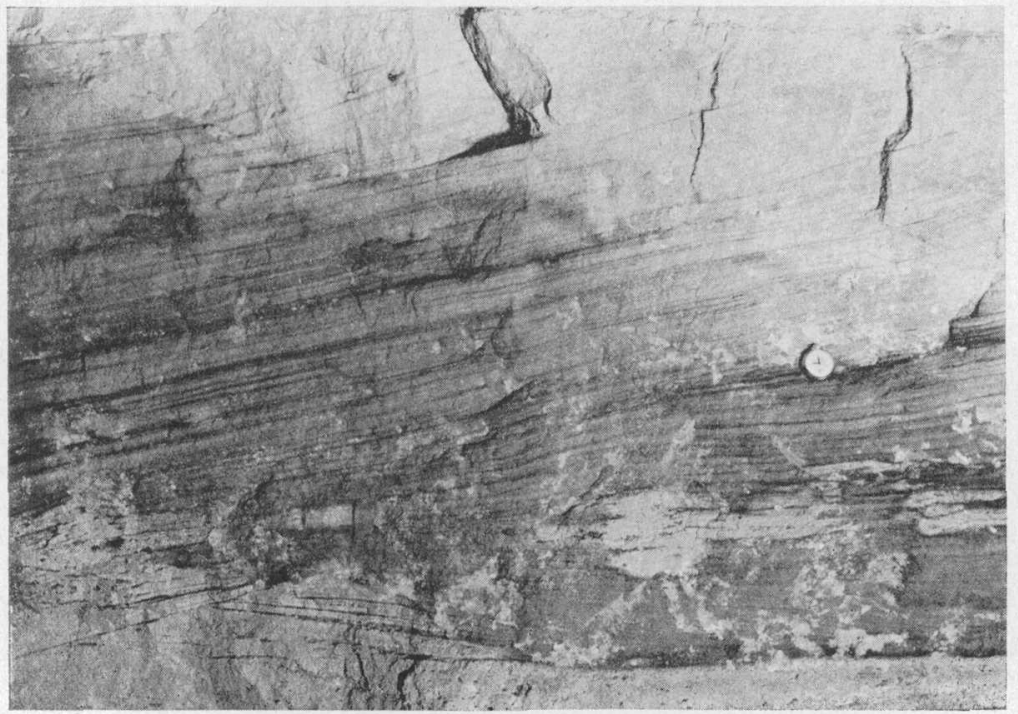

B. TYPICAL FACE OF VANADIUM ORE.

The ore (dark) is composed of vanadium-bearing hydrous mica in part disseminated in the sandstone and in part concentrated in sheets along bedding planes. This face of ore is about 2 feet thick and assays about 2 percent $\mathrm{V}_{2} \mathrm{O}_{5}$. Club group of mines. 


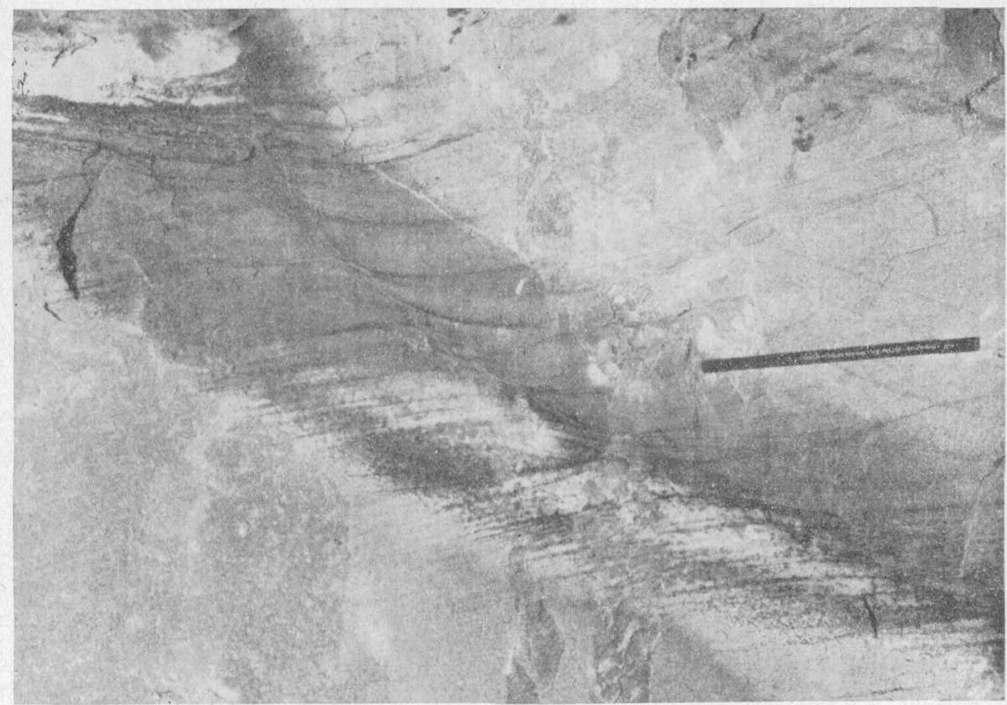

A. ZONE OF VANADIUM ORE CUTTING ACROSS BEDDING.

The ore (dark) cuts across the bedding, forming a roll, in barren sandstone (light). Note the slumping of the bedding planes across the central part of this zone, and the development of a fracture along the plane of greatest disturbance as a result of the removal in solution of the grains of quartz sand. Club group of mines.

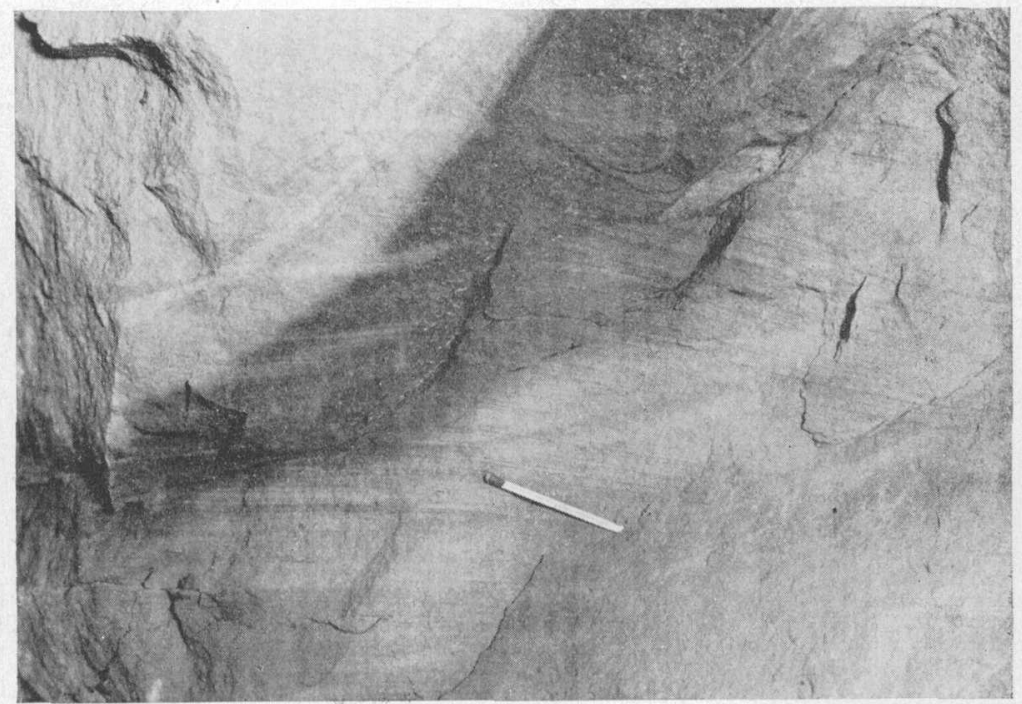

B. THIN ZONE OF RICH VANADIUM ORE (DARK) ALONG CONTACT OF ORE BODY (TO RIGHT) AND BARREN SANDSTONE (UPPER LEFT).

Club group of mines. 


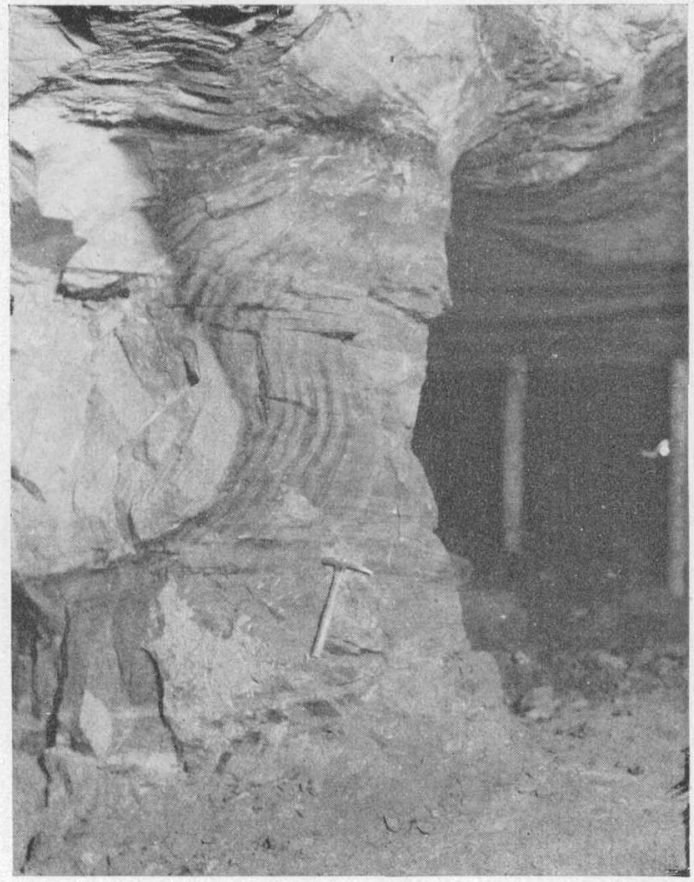

A. PARALLEL ZONES, RESEMBLING DIFFUSION BANDS, OF RICH VANADIUM ORE (DARK) ALONG THE EDGE OF AN ORE BODY.

Saucer Basin mine.

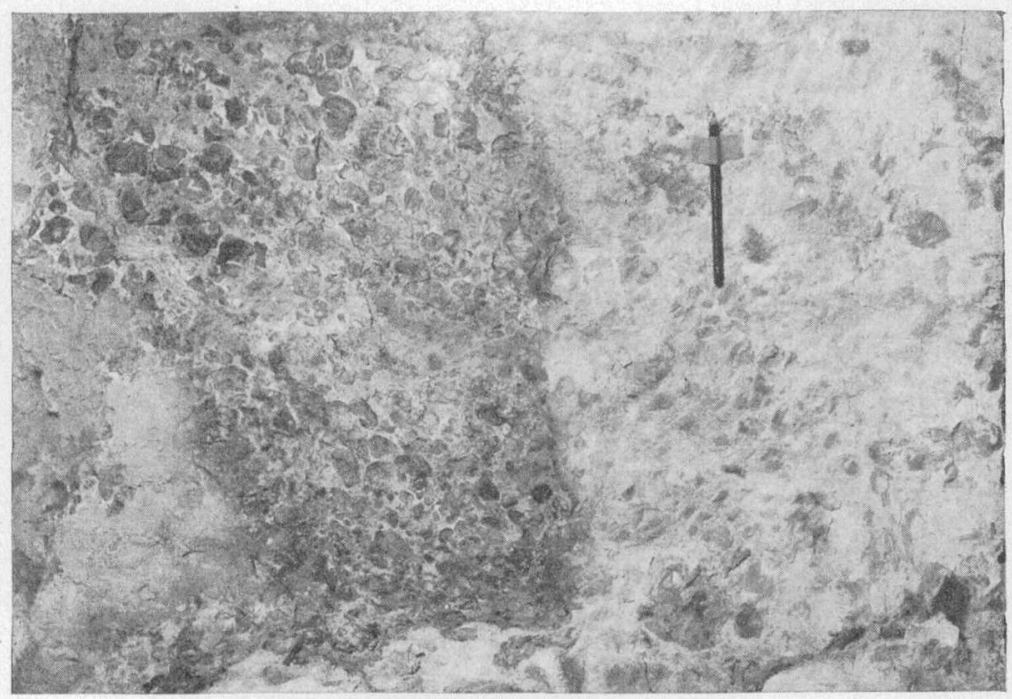

B. LENS OF SHALE-PEBBLE CONGLOMERATE, IN PART MINERALIZED (DARK) AND IN PART BARREN (LIGHT).

The boundary of the ore, in the middle of the picture, cuts sharply across the shale-pebble lens. Little Dick mine. 
defined, and mineralized sandstone too thin or too lean to be profitably mined extends considerably beyond the limit of minable ore. The ore bodies are so irregular in form that they cannot readily be classified. They consist of well-defined and poorly defined masses, both of which may be present in a single ore body.

The bodies with well-defined limits vary greatly in lateral dimension but are thin; usually the thickness of the ore is only - a few feet, but in places it is as much as 15 feet. Although irregular in detall, bodies of this type are essentially lensshaped--many tend to be somewhat convex upward (see flg. 46).

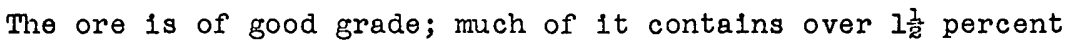
$\mathrm{V}_{2} \mathrm{O}_{5}$. One of the peculiar characteristic features of these bodies is the tendency for the better-grade ore to 110 along the margins of the bodies.

Where the boundary of the ore is especially sharp, vanadium minerals have been concentrated in a thin zone along the contact of ore and barren rock, forming what the miners call a roll (see pp. 379-380). Actually, the term roll as used by the miners often applies to the body of good ore that is adjacent to or partly enclosed within this curved surface. Two general types of rolls have been noted along the sides of the ore bodies: one is a roll convex outward from the ore body, and the other is convex toward the ore body, with thin tongues of ore extending along favorable bedding planes beyond the Ilmit of the commercial ore (see fig. 46). One type of roll may merge laterally into a roll of the other type, the form of the roll apparently being controlled by the lithologic character of the sandstone rather than by some pre-ore structure Imposed on the sandstone. Rolls also form wavy surfaces on the tops and bottoms of the ore bodies and seem to be more common and better developed on the top than on the bottom. Along the rolls, where mineralization was strong, some quartz has been dissolved (see 
pp. 379 and 380 ), and the resulting concentration of the vanedium-bearing hydrous mica makes a plane of weakness to which the rock breaks in mining. At most places where rolls lie along the edges of the ore bodies, mineralization of the sandstone extended only an Inch or two beyond the surface of the rolls.

Many of the rolls are small and irregular, but some of the larger and better developed ones are elongate, and some extend continuously for 50 or 60 feet. The conspicuously elongate rolls are orlented in a common direction in many ore bodies.

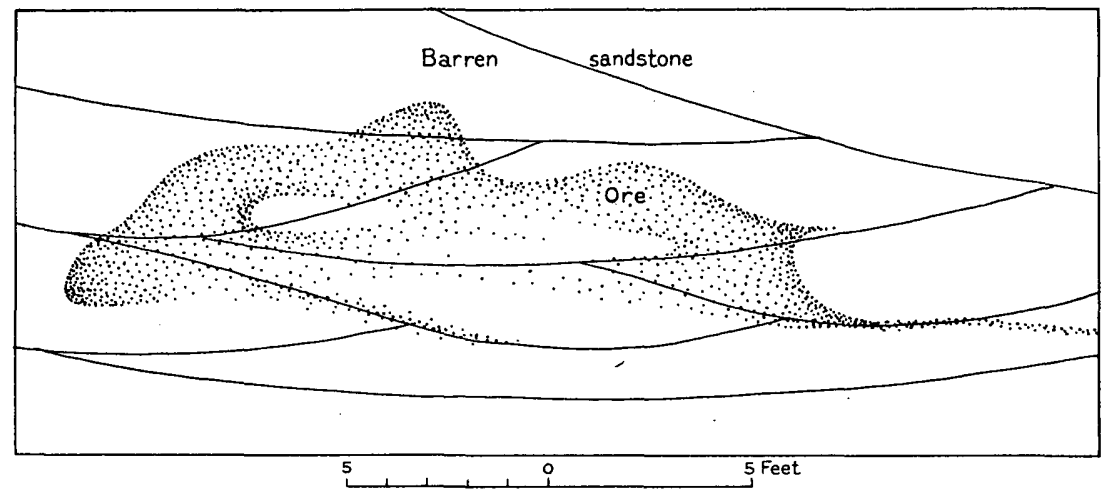

Figure 46.--Cross section of an ideal ore body with well-defined limits, showing (1) lens shape, tendine to be somewhat convex upward, (2) tendency for the better grade of ore to lle along the margins of the body. and (3) undulant rolls on the top and curved rolls on the sides of the body (on the left side of the sketch the roll is convex outward from the ore hody, and on the right side the roll is convex toward the body with thin tongues of ore extending beyond the limit of minable ore).

This direction seems to colncide with the trend or elongation of those ore bodies, and any adjacent ore bodies are likely to lie along this trend. The orientation of the rolls may thus be a useful guide in prospecting.

The bodies with poorly defined limits are mostly large and thick bodies of low-grade ore $\left(1\right.$ to $1 \frac{1}{2}$ percent $V_{2} \mathrm{O}_{5}$ ) in relatively massive, clean sandstone. The ore decreases in grade laterally and vertically, and weakly mineralized sandstone may extend considerably beyond the limits of commerclal ore. Rolls are not common in bodies of this type. Examples of such ore bodies are found at several places in Dry Valley, Utah, in the 
Ophir mine and in the Jo Dandy mine, Montrose County, Colo., and in the Bear Creek mine of the Placervilie district, Colo. It has been reported by Coffin, and it is the opinion of some miners, that joints related to reglonal stmactures may locally either cause an abrupt change in the thickness in the ore or may border the ore, as if these joints controlled the lateral movement of the ore-depositing solutions. But during many months of detailed study of these ores no joint related to regional structures was seen that definitely controlled the thickness or distribution of the ore. In places, the intersection of a roll surface and joint plane with a mine wall gives, on casual observation, the false impression of such control. In other places, postmineral faults, which have a horizontal displacement of a few feet but a vertical displacement of only a few inches, cause the ore to appear to end or abruptly change in thickness at the fault plane. All joints related to regional structures are believed to have been formed later than the early ore minerals.

Uravan district.--Figure 47 is a simplified geologic map of the Uravan district, Colo., showing the plan of the ore bodies that have been mapped by the Geological Survey, the location of the vanadium-bearing prospects and outcrops, and the outcrop of the base of the principal ore-bearing sandstone. The ore bodies In the Long Park area, in the southern part of the district, are alined in a northwesterly direction. Rolls and trends are not well developed in the individual ore bodies, but the majority of those that have been noted have northwesterly directions. Mos.t of the rolls in the Saucer Basin mine (near the west end of the cross section) have an easterly trend. No trends have been observed in the ore bodies of the Dolores group of mines, in the northwest corner of the district.

10/ Coffin, R. C., Radium, uranlum, and vanadium deposits of southmestern Colorado: Colorado Geol. Survey Bull. 16, p. 162, 1921. 
The ore bodies of the Club group of mines, about a mile southwest of Uravan, form one of the largest known groups in
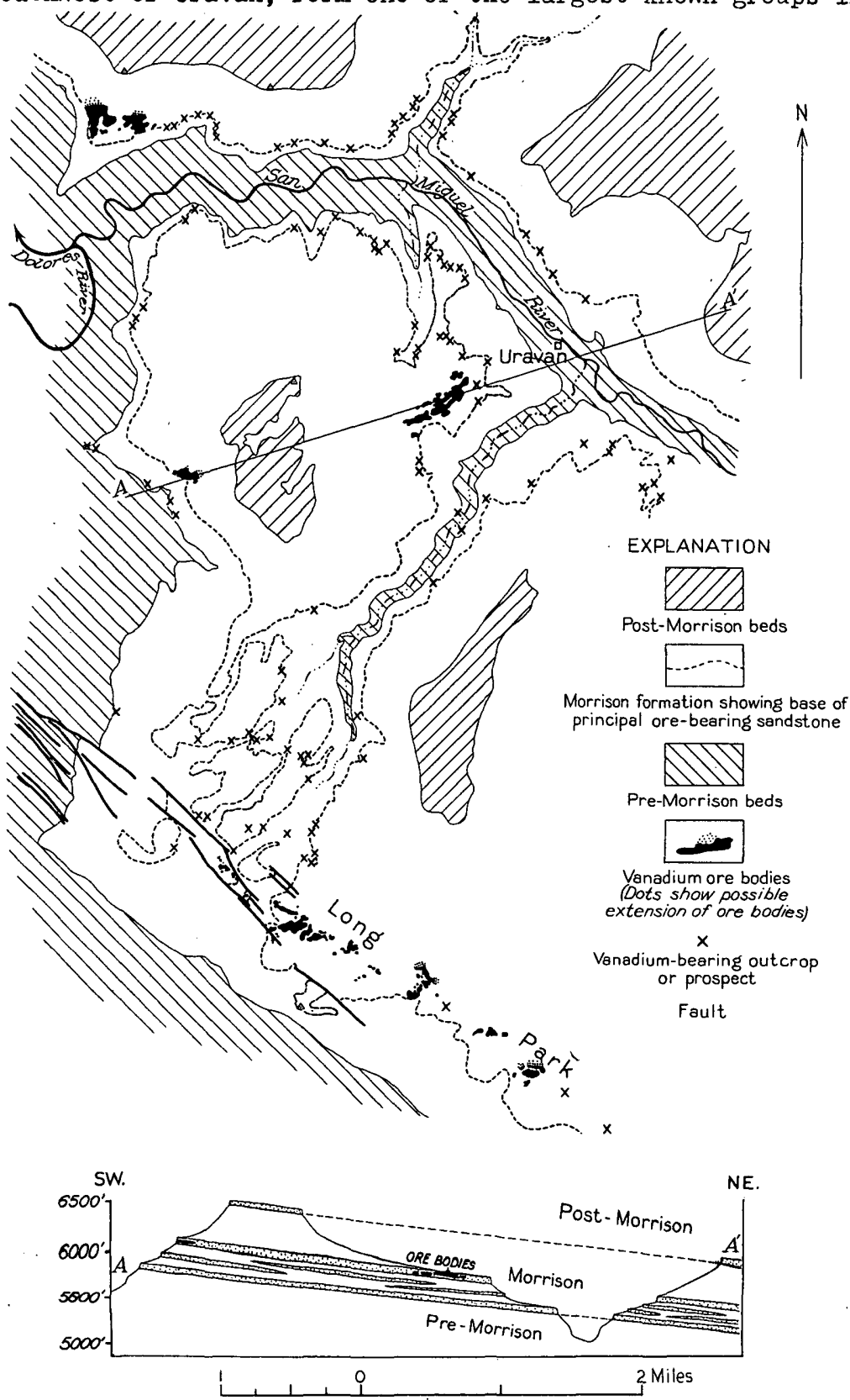

Figure 47.--Goologic map of the Uravan area, Montrose County, Colorado. the region, and they have yielded more than 150,000 tons of ore. It is estimated that this ore contained about $7,000,000$ pounds of $\mathrm{V}_{2} \mathrm{O}_{5}$, but only a small part of the vanadium contained 


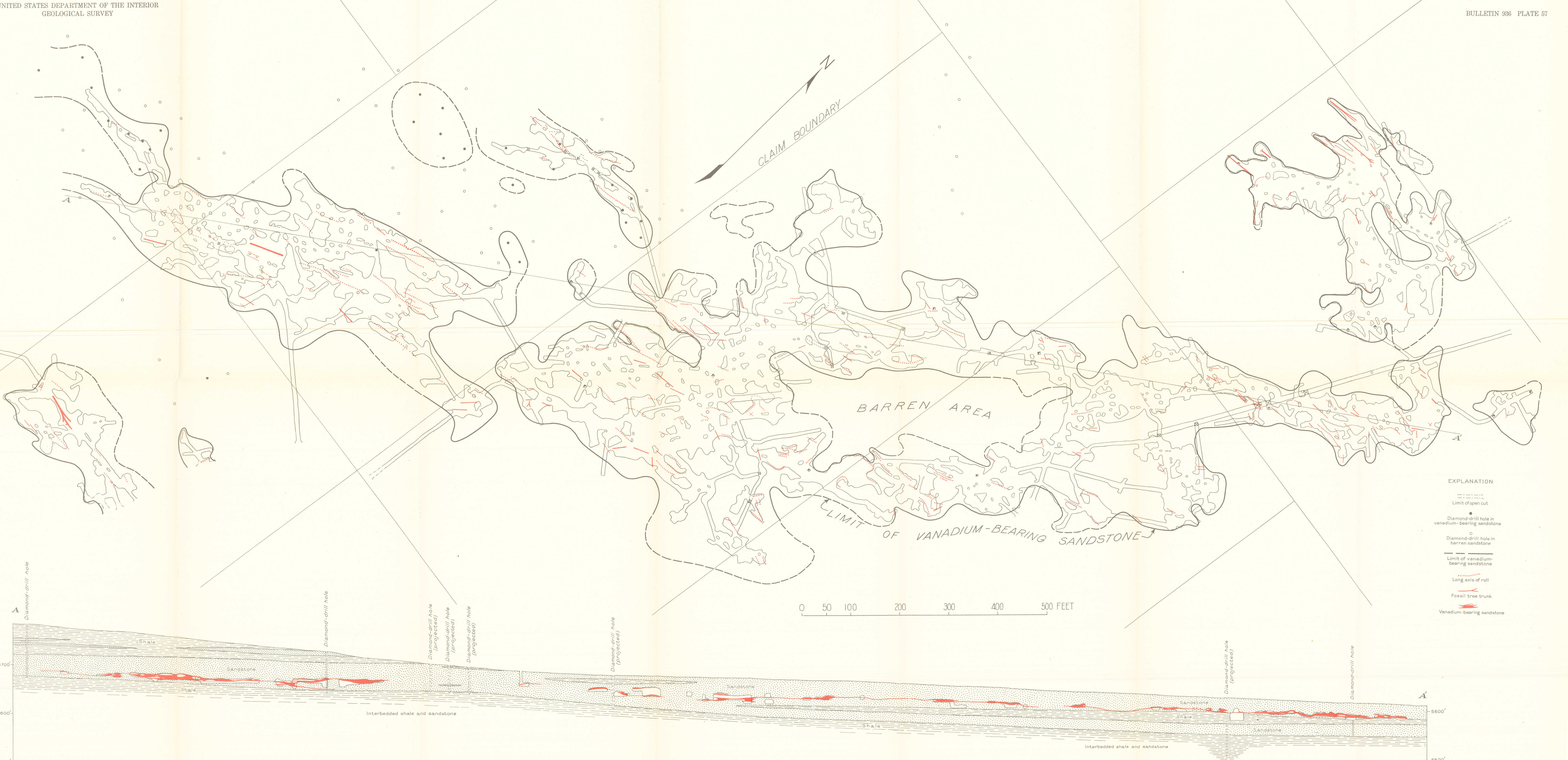


In the ore mined during the period 1911-1923 was recovered. Plate 57 shows in detall the ore bodies and the mine workings of this group. The limit of the vanadium-bearing sandstone, shown by the heavy line on plate 57, was determined by direct observations underground and by many drill holes not shown on the map.

The ore bodies of the Club group mostly belong to the type having well-defined limits, although some of the ore is massive and of low grade and has poorly defined limits. The group of ore bodies as a whole is alined in a northeasterly direction, but individual elongate bodies and the conspicuous lobes of the bodies of irregular outline are oriented about N. $70^{\circ} \mathrm{E}$. This trend is even more clearly shown by the orientation of the larger and better developed rolls within the ore bodies (see pl. 57). The area most favorable for prospecting lies southwest of the mines. Here, however, the ore-bearing sandstone is rather deeply buried and for that reason has not been much prospected.

Many of the logs or trees that were buried in the sandstone and have been exposed in the mine workings are also oriented in an easterly or northeasterly direction (pl. 57). In most mines, however, the logs do not have a common orientation and hence are not considered to be reliable indicators of ore trends.

\section{Origin and control of ore}

The origin of the ore and the factors that controlled its localization cannot yet be satisfactorily explained. The ore minerals impregnate sandstone and in their present form were deposited from.solutions after the sands were deposited, but the nature of the solutions is not understood, nor is the immediate source of the metals apparent. ,

All joints related to regional structures are belleved to have formed later than the early ore minerals (see p. 385). There are only four known localities in the reglon where ore 
minerals, other than the obviously secondary minerals, appear to be localized by faults. At Temple Mountain, Enery County, Utah, according to Hess, vanadium and uranium minerals were dissolved from ore bodies in the shinamum conglomerate and were deposited in small quantities along fractures in the overlying Chinle formation and "lowest Jurassic sandstone" (Wingate). Along a disturbed and faulted zone at Richardson, Grand County, Utah, vanadium and uranium minerals have been sparsely deposited in sandstone considered to be wingate. ${ }^{12 /}$ Coffin $13 /$ reports carnotite stains in Carboniferous and Dolores (Triassic) beds in faulted areas in Gypsum Valley, San Miguel County, Colo. (The unit mapped as Dolores by Coffin also includes beds now recognized as Wingate sandstone and Kayenta formation in addition to the Dolores formation.) Along Roc Creek, in Montrose County, Colo., small quantities of vanadium and uranium minerals occur in Wingate sandstone near a down-faulted block of ore-bearing Morrison. All other faults cut and displace the ore and appear to be later than the ore. Furthermore, when the region is viewed as a whole, the spacial distribution of the ore bodies fails to suggest any genetic relationship to faults or folds. The only practical importance of faulting and folding consists in their having affected the position of the productive beds.

In most areas the ore is largely or wholly confined to sandstone of a certain stratigraphic zone. Some favorable conditions must have existed in this zone to localize the ore, but these conditions have not been recognized. Sandstones similar or identical in appearance to the sandstone of the favorable stratigraphic zone lie below or above this zone, but contain little or no ore. Within the favorable stratigraphic zones, however, the ore bodies, are not confined to a single sa: dstone

11/ Hess, F. L., Uranium-bearing asphaltite sediments of Utah: Eng. and Min. Jour.-Press, vol. 114, p. 274, 1922.

12/ Dane, C. H., Geology of the Salt Valley anticline and adjacent areas, Grand County, Utah: U. S. Geol. Survey Bull. 863, pl. 1, 1935.

13/ Coffin, R. C., op. c1t., p. 153. 
bed or to a single lithologic type of sandstone. Shale pebbles, clay films along bedding planes, and fossil plants commonly localize high concentrations of the metals within ore bodies, but since these lithologic features are as abundantly present in the adjacent barren sandstone as in the ore, they cannot have controlled the position of the ore bodies. No evidence has been found of mechanical deposition and concentration of vanadiumand uranium-rich material that might have accumulated as the sands were deposited and might, therefore, have served as the Immediate source of these metals.

The primary ore minerals are thought to have been introduced into their present position not long after the sands were deposited. If this is true, the metals were probably transported and deposited by ground waters, and the ores were probably localized by delicate chemlcal and physical conditions that now cannot be definitely recognized. This hypothesis probably requires at least three separate periods of ore deposition, to account for the ore in the Shinarump, Entrada, and Morrison formations.

\section{SUGGESTIONS FOR PROSPECTING}

As long as the origin of these deposits remains undetermined, the localization of the ores cannot be satisfactorily explained, but certain observed facts regarding their localization may be useful as guides in prospecting.

Stratigraphic zones locally favorable for ore should be recognized and prospecting and development restricted to them. In the Placerville district the ore-bearing Entrada sandstone is Immediately overlain by the Pony Express limestone member of the Wanakah formation, which makes an easily recognized stratigraphic marker. At the Rifle deposit the top of the underlying red beds similarly serves as a stratigraphic plane of reference.

2lt/ The Pony Express limestone member has been called the Laplata limestone in the San Juan Mountain region. 
In the Morrison formation, on the other hand, there is no definite bed or plane that can be used as a stratigraphic guide. The ore-bearing sandstone is underlain by red shale, which is altered to gray or greenish-gray in the upper few feet--the blue clay of the miners and drillers (p. 376). It is a common practice to bottom drill holes in the red shale immediately below the blue clay. Not all holes should be abandoned immediately on reaching red shale, however, for in places a lens of red shale, altered to gray or greenish gray in the upper few feet, is interbedded with or lies within the ore-bearing sandstone (see cross section, pl. 57). Since many vanadium ore bodies lie In the lower part of the ore-bearing sandstone, it is desirable to drill through this sandstone. Where holes are drilled near canyon walls, subsurface stratigraphic conditions can be interpreted from exposures along the cliffs. Where drilling is undertaken some distance from canyon walls several holes in a group should be continued to a considerable depth in order to explore subsurface conditions and definitely establish the base of the ore-bearing sandstone.

Many ore bodies are elongate, and in places the trend of this elongation is indicated by the orientation of rolls in the ore. The mapping of ore bodies and rolls shows this trend, thus pointing to the areas most favorable for additional prospecting and aiding in planning development. In one mine studied, the mine workings first opened were elongated in a northeasterly direction, but the orientation of the rolls suggested a northwesterly trend. Subsequent arilling, encircling theso mine workings, disclosed previously unsuspectod oxtensions of the ore body to the northwest and southeast. The trend indicated by. the elongation of an ore body, or by the rolls within an ore body, may also indicate the general alinement of any nearby ore bodles. 
Where rolls lie along the sides of ore bodies the sandstone tends to break to the curved surface of the roll, leaving what looks like a face of high-grade ore. As the ore minerals penetrate the sandsitone only an inch or two beyond this surface, however, channel samples cut from mine walls at such places have no practical use and give an entirely false concept of the value of this face. Diamond drilling from the surface has so far proved to be the most satisfactory method of subsurface prospecting where the sandstone favorable for ore is not too deeply buried. With the light drill rigs commonly used in the ColoradoUtah region, it is rarely feasible to drill deeper than about 125 feet, but these rigs have the advantage of being easily moved and set up. A common practice is to encircle an ore body with drill holes when underground workings cease to develop new ore. The trend indicated by rolls or a pronounced elongation of the ore body should aid in determining the most favorable places to drill, but not all drilling should be restricted to the indicated trends, for some ore bodies, such as those in the Club group of mines (pl. 57), are alined in an en echelon pattern, and in places elongate bodies have been found lying side by side rather than end to end.

Because of the extreme spottiness of ore bodies and the large ratio of barren to mineral1zed ground (f1g. 47), w1ldcat drilling, at some distance from known ore bodies, should be largely restricted to established alinements. Wildcat driling across the recognized alinement in Long Park, Montrose County, Colo., has disclosed several ore bodies more than a thousand feet from ground previously known to be mineralized.

Subsurface prospecting by underground drifting is useful in places, especially where diamond drilling is not feasible because of excessive depth to the ore-bearing sandstone. It is inadvisable to drift blindly through barren sandstone, but it is good practice to follow thin tongues of vanadium-bearing 
sandstone that extend laterally beyond the limits of commercial ore--drifts following these tongues have led to new ore bodies. As the sandstone is not hard, such drifting is not very costly, and it may, too, be partly paid for by the vanadium-bearing sandstone broken in the drift, for the mineralized tongues, though too thin to be mined for their own sake, contain in places as much as 3 or 4 percent $\mathrm{V}_{2} \mathrm{O}_{5}$. This manner of prospecting is especially applicable in the Placerville district, where steep valley walls and thick overburden make diamond drilling impracticable.

of the several methods of geophysical prospecting that have been tried, the detection of radioactivity by the Geiger-Muller counter appears to be the most effective. This method detects only the radioactive disintegration products of uranium, but as significant quantities of uranium are everywhere associated with the vanadium ores in the Morrison formation and the Shinarump conglomerate, the method should be applicable in diamond drilling and underground prospecting. Kelly found that apparently barren sandstone, cored from a horizon as much as 20 feet above ore, gave distinct gamma-ray evidence of radioactivity. It is believed that a similar effect should be obtained from sandstone a short distance laterally from ore bodies. As the rock surrounding ore is not visibly altered and contains no distinctive minerals, drill holes that penetrate barren sandstone within a short distance of ore show no visible evidence that ore is near. This sandstone, however, may well be somewhat radioactive, and with the aid of the Geiger-Muller counter it might be possible to find evidence of the proximity of ore in holes as much as 15 or 20 feet from an ore body. Further systematic studies are needed to establish. and evaluate the possibilities offered by this technique.

15/ Relly, S. I., Geological studies of vanadtum-uranium deposits by geophysical exploration methods: Min. Cong. Jour., vol. 27, pp. 27-35, 1942. 
The Geiger-Muller counter appears to have similar application underground in indicating bodies or pockets of ore that lie near mine workings but have been overlooked during mining.

Electrical, magnetic, and electrical-resistivity methods of geophysical prospecting cannot be successfully applied directly to the ore itself, but an indirect application of the electrical resistivity method is reported to have met with some success. 17 Where the ore-bearing sandstone is not too deep, this method can be applied to determine the thickness of the sandstone and to delinit areas in which the sandstone, being unsually thick, is presumably more favorable for ore.

\section{MINING AND MILLING}

\section{Prospecting}

Two general methods of prospecting are now employed: (I) The most common practice is to follow the outcrop of the orebearing sandstone, looking for showings of ore on the cliff face, and for float of ore on the slopes below. (2) Diamond drilling is confined mostly to areas indicated as favorable on the basis of past production or by established ore trends. Where depth to the ore-bearing sandstone is not excessive--the usual limit being about 125 feet--mines approaching exhaustion are encircled by drill holes, the spacing of the holes being controlled by local conditions. In wildcat drilling, at some distance from known ore bodies but along established alinements, it is common practice to drill holes 100 feet apart on a line across the trend. Where ore is encountered, holes are drilled at closer Intervals, but no attenpt is made to block out more ore than is necessary to justify the estimated cost of opening the body for mining.

16/ Kelly, s. F.. op. c1t., p. 35.

17) Idem, pp. 27-35. 


\section{Mining}

Mining methods differ with the size of the mine. In small mines, where no more than three or four men are employed, the common practice is merely to follow the ore in mining. Drilling is done by hand or with a jackhammer driven by a small, portable compressor. Average production ranges from $\frac{1}{2}$ to 1 ton of ore per man-shift. In larger mines more systematic mining methods are used. The general practice is to drive one or more drifts through the ore, possibly to the commercial limits of the body, and to mine from these by irregularly spaced side drifts, leaving pillars of low-grade ore and barren rock. Vertical stulls are used in places. Ore pillars are robbed and the ground allowed to cave on final retreat from the mine. Tramming is done by hand, but electric, compressed air, or gasoline-driven hoists are used for raising the ore up inclines. Alr compressors are driven by gasoline or Diesel engines. Production ranges from 1 to 2 tons of ore per man-shift. In order to avold too much hand sorting an effort is made to shoot ore and waste rock separately.

\section{Miling}

Ore is trucked to the mills from many widely scattered operations. At the mill the ore is crushed, mixed with common salt, and roasted, converting the vanadium minerals into a soluble sodium vanadate, which is then leached by water. Acid is added to the solution, precipitating the sodium vanadate. The precipitate may be sacked ana shippod in this form, but at most mills it is fused before shipment. 